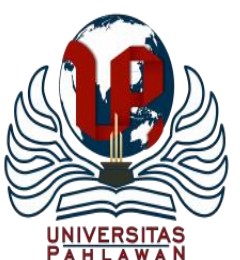

Jurnal Basicedu Volume 4 Nomor 4 Tahun 2020 Halaman 1398-1407

JURNAL BASICEDU

Research \& Learning in Elementary Education

https://jbasic.org/index.php/basicedu

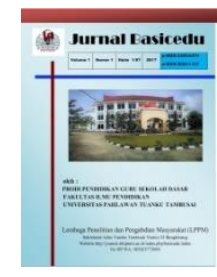

\title{
Analisis Buku Teks Pelajaran Bahasa Inggris SD Berdasarkan Karateristik Pembelajar Muda pada Kelas Rendah
}

\author{
Vitri Angraini Hardi ${ }^{1}$, Muhammad Syahrul Rizal ${ }^{2}$ \\ Email : vitrianggraini@universitaspahlawan.ac.id¹, syahrul.rizal92@gmail.com
}

\begin{abstract}
Textbook is composed to stimulate students' engagement on learning materials. The research aims to explore the suitability of textbook use in research and students' characteristics in English Foreign Language Learning. Research was conducted based on Grade III students' characteristics of SD Pahlawan. The research employed a qualitative research with researcher as the main instrument. In further, to get valid data, the research employed triangulation technique on research instruments. The research began with interview to English Teacher of grade III students of SD Pahlawan. Observation sheet and document were used to obtain in-depth data of the research. The research continued with semi structured interview with the teacher. It revealed that a good textbook should able to ease the students in understanding the learning materials. Among 7 indicators of grade III elementary students' characteristics, textbook used has filled up students' characteristic even another 1 indicators could not found in the textbook use. Mostly, it could be stated that textbook use in English Learning is suitable with students' characteristics.
\end{abstract}

Keywords: textbook, students' characteristics

\begin{abstract}
Abstrak
Buku teks pembelajaran saat ini memiliki fungsi untuk meningkatkan keaktifan siswa berdasarkan kandungan yang disajikan. Tujuan penelitian ini untuk mendeskripsikan kesesuaian antara buku teks Bahasa Inggris yang digunakan oleh sekolah yang dijadikan sebagai objek penelitian dan karakteristik siswa yang mendukung dalam pembelajaran pada bidang bahasa. Strategi penelitian yang digunakan adalah analisis terhadap buku teks bahasa Inggris berdasarkan karakteristik siswa kelas III SD Pahlawan. Penelitian ini menggunakan metode kualitatif dengan peneliti merupakan instrument kunci. Namun untuk mendukung proses penelitian, dilakukan triangulasi instrument penelitian. Penelitian ini diawali dengan wawancara lapangan kepada narasumber yaitu guru SD Pahlawan yang mengampu mata pelajaran bahasa inggris di kelas III SD Pahlawan. Kemudian, instrument lainnya yang digunakan pada penelitian ini adalah lembar ceklis dan dokumentasi kegiatan untuk memperkuat temuan data. Selanjutnya peneliti menggunakan teknik triangulasi untuk memeriksa keabsahan data dengan melakukan wawancara ulang kepada narasumber sebanyak dua kali. Dalam penelitian ini ditemukan bahwa buku teks sebagai bahan ajar dituntut untuk mampu mempermudah siswa dalam memahami pembelajaran. Sejalan dengan hal tersebut, buku teks yang baik dalam pembuatannya melibatkan karakteristik siswa. Hal ini dikarenakan karakteristik mempengaruhi kegiatan pembelajaran. Karakteristik berkaitan dengan kualitas diri yang dimiliki seorang individu. Memahami karakter berarti melakukan identifikasi terhadap individu. Hal ini penting dikarenakan ada hubungan yang kuat antara katrakter siswa dan proses pengembangan instruksional dan Tingkat Kesiapan Teknologi (TKT) yang dihasilkan dari penelitian ini adalah berupa konsep terkait kesesuaian karakteristik siswa dan buku teks yang digunakan.
\end{abstract}

Kata Kunci: Buku Teks; Karakteristik; Siswa.

Copyright (c) 2020 Vitri Angraini Hardi, Muhammad Syahrul Rizal

$\triangle$ Corresponding author :

Address : -

ISSN 2580-3735 (Media Cetak)

Email : :

ISSN 2580-1147 (Media Online)

Phone : -

DOI: https://doi.org/10.31004/basicedu.v4i4.605 


\section{PENDAHULUAN}

Buku teks merupakan penunjang utama kegiatan pembelajaran di dalam maupun di luar kelas. Ketersediaan buku teks mampu memanipulasi cara berpikir siswa. Melalui buku teks, siswa mampu mengumpulkan pengetahuan dan mempraktikkan keterampilan. Permendiknas (2005) Pasal 1 mengemukakan bahwa Buku teks pelajaran adalah buku acuan wajib untuk digunakan disekolah -sekolah yang memuat materi - materi pelajaran dalam rangka peningkatan keimanan dan kataqwaan, budi pekerti dan kepribadian, kemampuan penguasaan ilmu pengetahuan dan teknologi, kepekaan dan kemampuan estetis, potensi fisik, dan kesehatan yang disusun berdasarkana standar nasional pendidikan. Buku teks dibuat disesuaikan dengan mata pelajaran yang ada di sekolah.

Berdasarkan uraian di atas, berarti pembelajaran merupakan suatu proses yang kompleks dan melibatkan berbagai aspek yang saling berkaitan. Oleh karena itu, untuk menciptakan pembelajaran yang aktif dari siswa diperlukan berbagai keterampilan. Keterampilan tersebut, di antaranya adalah keterampilan belajar maupun keterampilan mengajar. Keterampilan mengajar merupakan kompetensi professional yang cukup kompleks termasuk membuat buku teks sebagai bahan ajar yang akan dapat difahami oleh siswa dengan mudah dan dan merasa proses pembelajaran menjadi lebih menyenangkan.

Menurut Tarigan (2009:24) faktor penentu kualitas buku teks dapat dibedakan menjadi : Sudut pandangan, kejelasan konsep, relevan dengan kurikulum, menarik minat, menumbuhkan motivasi, menstimulasikan aktivitas, ilustratif, komunikatif, penunjangan mata pelajaran lain, menghargai perbedaan individual, memantapkan nilai-nilai. Keterlibatan masing - masing komponen dikarenakan adanya banyak hal yang harus dipersiapkan dalam menyajikan buku teks sebagai bahan ajar. Ditilik dari pendapan Tarigan diatas, secara umum faktor penimbang hadirnya sebuah buku teks dalam pembelajaran adalah pemakainya, dalam hal ini siswa. Keberadaan siswa merupakan tolak ukur konkret untuk melihat hasil sajian sebuah buku teks. Menurut Dick dan Carey dalam Sitanggang (2013:186) mengemukakan bahwa identifikasi karakteristik siswa sangatlah penting karena dengan alasan berimplikasi pada proses mengembangan instruksional anak. Buku Teks perlu disesuaikan dengan pemakainya, karena buku teks tersebut diberlakukan di sekolah, sehingga sasaran pertama ialah siswa, karakteristik siswa memberikan pengaruh terhadap perkembangan belajar anak, dimana setiap siswa memiliki karakter yang berbeda-beda yang perlu diperhatikan dalam proses belajar karena berpengaruh terhadap tujuan pendidikan.

Disisi lain, konsep pengajaran bahasa (asing) yang tertuang dalam buku teks pembelajaran seharusnya tidak terlepas dari konsep belajar itu sendiri. Semakin baiknya pemahaman terhadap hakikat perkembangan anak telah melahirkan pandangan konstruktivisme dalam pembelajaran. Terkait dengan belajar bahasa, hal terpenting yang harus dipahami adalah bahwa belajar bahasa adalah suatu proses akuisisi dengan tujuan tercapainya kemampuan siswa untuk berperan aktif dalam proses belajar

Hasil wawancara di lapangan ditemukan bahwa beberapa materi mengalami perubahan letak sejalan dengan perubahan yang terjadi pada kurikulum. Beberapa materi yang pernah di muat pada Buku Teks sebelumnya mengalami perbedaan dengan buku teks yang digunakan pada tahun tersebut. Hal ini tentunya dikarenakan faktor perubahan pada kurikulum. Materi ajar yang disajikan kadang menuntut guru untuk mengupayakan pembelajaran lebih. Materi ajar yang digunakan bersumber dari buku yang digunakan di beberapa sekolah. Sekolah mengikuti penggunaan buku yang sudah pernah digunakan di sekolah lainnya. Secara jelas dapat dilihat bahwa masing - masing sekolah di isi oleh masing - 
masing siswa yang berbeda. Hal ini tentu menghadirkan karakter siswa yang juga berbeda. Keseragaman penggunaan buku teks yang dihadirkan kepada siswa tidak menjamin akan menghasilkan luaran pembelajaran yang sama.

Dilihat dari paparan diatas dapat dikatakan bahwa penting perlunya dilakukan suatu penelitian ilmiah untuk melihat gambaran relevansi buku teks yang digunakan khususnya pada pembelajaran bahasa inggris di kelas III dengan karaktersitik penggunanya. Hal ini akan memberikan kontribusi secara signifikan terhadap hasil dan capaian pembelajaran kepada siswa. Lebih jauh ini akan menggiring guru dengan mudah untuk mengemas suatu kegiatan pembelajaran yang ringan dan mampu diserap oleh siswa dengan maksimal.

Ditarik dari latar belakang di atas, maka dapat dirumuskan permasalahan sebagai berikut :

Bagaimana kesesuaian karakteristik peserta didik pada kelas rendah dengan buku ajar teks Bahasa Inggris yang digunakan oleh guru?

Perkembangan informasi pada saat sekarang ini semakin cepat meluas dan tersebar baik melalui media cetak maupun digital tentu menjadi tantangan bagi pelaku informasi sehubungan dengan informasi yang terkandung dalam sebuah buku akurat sehingga dapat menjadi rujukan yang baik dalam memenuhi kebutuhan informasi atau malah sebaliknya informasi yang disajikan tidak dapat memenuhi kebutuhan dasar pengguna informasi. Menurut Kurniasih (2014:60) buku adalah buah pikiran yang berisi ilmu pengetahuan hasil analisis kurikulum secara tertulis dan buku disusun menggunakan bahasa sederhana, menarik, dilengkapi gambar serta dafta pustaka. Ham and Heize (2018) menyatakan bahwa buku teks mamfasilitasi guru dan siswa tentang tujuan pembelajaran yang akan dicapai. Buku Teks merupakan mediator antara kurikulum yang telah ditetapkan dan kurikulum yang diterapkan guru (Ham and Heize, 2018)
Jenis buku yang sangat penting dan fungsional bagi siswa adalah buku teks pelajaran. Buku teks pelajaran dapat memberikan motivasi belajar bagi siswa dalam berbagai mata pelajaran.Peraturan Menteri Pendidikan Nasional Nomor 2 Tahun 2008 tentang Buku menjelaskan bahwa :

"Buku teks pelajaran pendidikan dasar, menengah, dan perguruan tinggi yang selanjutnya disebut buku teks adalah buku acuan wajib untuk digunakan disatuan pendidikan dasar dan Menengah atau perguruan tinggi yang memuat materi pembelajaran dalam rangka peningkatan keimanan, ketakwaan, akhlak mulia, dan kepribadian, penguasaan ilmu pengetahuan dan teknologi, peningkatan kepekaan dan kemampuan estetis, peningkatan kemampuan kinestetis dan kesehatan yang disusun berdasarkan standar nasional pendidikan."

Buku Teks, Pengertian buku teks pelajaran seperti yang dikutip dari Permendiknas Nomor 2 tahun 2018, menentukan kedudukan buku teks pelajaran sebagai buku acuan wajib. Menurut Tarigan (2009:24) Faktor penentu buku teks dapat dibedakan menjadi : sudut pandangan, kejelasan konsep, relevan dengan kurikulum, menarik minat, menumbuhkan motivasi, menstimulasikan aktivitas, ilustratif, komunikatif, penunjangan mata pelajaran lain, menghargai perbedaan individual, memantapkan nilai-nilai.

Buku teks yang baik perlu memperhatikan kesesuaian materi dalam buku teks, kesesuaian materi ditentukan dari kompetensi dasar pada standar kompetensi, di nilai pada sisi relevan dengan buku teks yang digunakan. Anwar (2009:4) menyatakan hal-hal yang berhubungan dengan buku pembelajaran dapat dibedakan dari beberapa aspek diantaranya materi, penyajian materi, bahasa dan keterbacaan. pendapat ini menekankan bahwa penyajian buku teks, khususnya bidang studi bahasa Inggris dimana penyajian itu dapat berupa 
tujuan dari pembelajaran, kemenarikan siswa dan minat, kemudahan dalam pemahaman siswa, dan latihan soal yang mendukung bidang bahasa, dengan begitu buku teks dapat memberikan sarana untuk memudahkan siswa dalam pembelajaran. Buku Teks perlu disesuaikan dengan pemakainya, karena buku teks tersebut diberlakukan di sekolah, sehingga sasaran pertama ialah siswa, karakteristik siswa memberikan pengaruh terhadap perkembangan belajar anak, dimana setiap siswa memiliki karakter yangberbeda-beda yang perlu diperhatikan dalam proses belajar karena berpengaruh terhadap tujuan pendidikan.

Pembelajaran adalah usaha sadar dari guru untuk membuat siswa belajar, yaitu terjadinya perubahan tingkah laku pada diri siswa yang belajar, dimana perubahan itu dengan didapatkannya kemampuan baru yang berlaku dalam waktu yang relatif lama dan karena adanya usaha. Mengajar bukan hanya menyampaikan materi pelajaran, akan tetapi mengajar merupakan suatu proses mengubah perilaku siswa sesuai dengan tujuan yang diharapkan. Oleh sebab itu, dalam proses mengajar terdapat kegiatan membimbing siswa agar siswa berkembang sesuai dengan tugas-tugas perkembangannya, melatih keterampilan baik keterampilan intelektual maupun keterampilan motorik sehingga siswa dapat dan berani hidup di masyarakat yang cepat berubah dan penuh persaingan, memotivasi siswa agar mereka dapat memecahkan berbagai persoalan hidup dalam masyarakat yang penuh tantangan dan rintangan, membentuk siswa yang memiliki kemampuan inovatif dan kreatif, dan lain sebagainya.

Belajar adalah usaha sadar dari guru untuk membuat siswa belajar, yaitu

terjadinya perubahan tingkah laku pada diri siswa yang belajar, dimana perubahan itu

dengan didapatkannya kemampuan baru yang berlaku dalam waktu yang relatif lama

dan karena adanya usaha. Mengajar bukan hanya menyampaikan materi pelajaran, akan tetapi mengajar merupakan suatu proses mengubah perilaku siswa sesuai dengan tujuan yang diharapkan. Oleh sebab itu, dalam proses mengajar terdapat kegiatan membimbing siswa agar siswa berkembang sesuai dengan tugas-tugas perkembangannya, melatih keterampilan baik keterampilan intelektual maupun keterampilan motorik sehingga siswa dapat dan berani hidup di masyarakat yang cepat berubah dan penuh persaingan, memotivasi siswa agar mereka dapat memecahkan berbagai persoalan hidup dalam masyarakat yang penuh tantangan dan rintangan, membentuk siswa yang memiliki kemampuan inovatif dan kreatif, dan lain sebagainya.

Pembelajaran Bahasa Inggris Mempelajari suatu bahasa telah dilakukan oleh manusia semenjak lahir, mempelajari bahasa dimulai dari belajar bahasa ibu yang merupakan suatu hal yang alamiah. Namun berbeda dengan belajar bahasa kedua atau bahasa asing. Liitlewood (1984:3) membedakan kedua istilah ini, yaitu " $a$ "second" language has social functions within the communicaty where it is learnt (e.g.,) as a lingua franca or as the language of another social group), whereas a "foreign" language is learnt primarily for contact outside one's own community". Pendapat ini diartikan bahwa bahasa kedua memiliki fungsi social dalam masyarakat dimana ini di pelajari (misalnya, sebagai lingua franca atau bahasa kelompok sosial lain). Sedangkan bahasa asing dipelajari terutama untuk hubungan diluar komunitas sendiri.

Sementara itu nunan Nunan (2005:9) menyebutkan "the ability to use a second language (knowing "how") would develop automatically if the learner were required to focus on meaning in the process of using the language to communicate". Pendapat tersebut diartikan bahwa kemampuan untuk menggunakan bahasa kedua (mengetahui bagaimana) akan berkembang secara otomatis jika pembelajar diarahkan untuk fokus makna dalam proses menggunakan bahasa untuk berkomunikasi. Bahasa kedua yang dimaksud di sini adalah bahasa asing yang pada umumnya dipelajari olehsiswa di suatu lingkup sekolah. Bahasa asing diajarkan sebagai mata pelajaran di sekolah dengan tujuan agar siswa dapat berkomunikasi dengan orang asing atau untuk membaca bacaaan dalam bahasa asing tersebut. Pembelajaran bahasa inggris untuk anak-anak merupakan fenomena baru dalam dunia 
postmodern ini. Pembelajaran bahasa inggris untuk sekolah dasar didasari suatu pendapat bahwa belajar bahasa asing atau bahasa kedua akan lebih baik apabila dimulai lebih awal (Hammerly. 1982) . Teori lain yang mendukung pengajaran bahasa Inggris di sekolah dasar adalah teori afektif. Menurut Krashen (1982), proses belajar bahasa terjadi karena adanya input (masukan), baik tertulis maupun lisan.

Pembelajar Muda, merupakan siswa SD berusia antara 6-12 tahun atau 13 tahun yang dibagi dalam dua kelompok yaitu:Younger Group (6-8 tahun) dan Older Group (9-12 tahun). Menurut kelasnya dibagi menjadi lower class, yaitu anak kelas 1,2, dan 3 dan upper class, anak kelas 4,5, dan 6. Istilah lain adalah Level one atau tingkat pemula (5-7 tahun) dan Level Two (8-19 tahun). Kedua kelompok tersebut disebut juga dengan beginners jika mereka baru memulai belajar bahasa Inggris pada usia itu.

tepat untuk mereka. Karakteristik anak SD antara lain:

- Belajar sambil bermain, bernyanyi dan menggerakkan anggota tubuh.

- Mereka memiliki perhatian dan konsentrasi yang singkat (tidak tahan lama).

- Mereka juga belajar dengan baik ketika mereka diberi motivasi untuk terlibat secara langsung dalam kegiatan yang berhubungan dengannya. Misalnya, akan lebih mudah bagi mereka untuk mempelajari materi yang menggunakan kata atau frasa seperti “ My name is..... I have a cat.

- Jika suatu kalimat atau frasa berkaitan dengan benda-benda miliknya, anak akan memberi perhatian lebih kepada kalimat atau frasa tersebut.

- Mereka menyukai cerita sebagaimana mereka menyukai permainan. Melalui cerita, siswa dapat dilatih untuk lebih memusatkan perhatian pada konteks secara keseluruhan daripada jika dinyatakan kata per kata.
- Pada usia 10 tahun (kelas 3) anak mulai memperhatikan orang lain tidak lagi hanya berfokus

pada dirinya. Anak sudah mulai terbuka, misalnya sudah memperhatikan you, yaitu temannya.

- Untuk memperkenalkan bahasa Inggris kepada mereka, awali dengan hal yang konkret dan

disertai dengan objek atau benda nyata atau gambar dari kata-kata yang sedang dipelajari.

Benda-bena seperti kursi, meja, papan tulis, alatalat tulis dengan mudah dapat diperkenalkan kepada siswa.

\section{METODE}

Penelitian ini merupakan Penelitian Kualitatif yang berangkat dari fenomena adanya keterkaitan antara karakteristik siswa dan buku teks dalam keberlangsungan kegiatan pembelajaran. Ini merupakan analisis isi dengan menggunakan dokumen sebagai objeknya. Tujuan penelitian ini untuk mendeskripsikan kesesuaian antara buku teks Bahasa Inggris yang digunakan oleh sekolah yang dijadikan sebagai objek peneliti dan karakteristik siswa yang mendukung dalam pembelajaran pada bidang bahasa. Strategi penelitian yang digunakan adalah analisis terhadap buku teks bahasa Inggris berdasarkan karakteristik siswa yang ada di sekolah. Dokumen yang dianalisis adalah buku teks Bahasa Inggris yang digunakan pada Kelas III dan kelas VI di SD Pahlawan. Lokasi penelitian beralamatkan Jl.Akper, Desa Ridan Permai,Kec. Bangkinang Kota,Kab.Kampar.

Data yang akan dikaji pada penelitian ini adalah data kualitatif. Sumber data yang digunakan adalah buku teks Bahasa Inggris yang digunakan di SD Pahlawan pada kelas III dan kelas VI. Untuk memudahkan peneliti dalam melakukan penelitian, maka pengkodean dilakukan seperti pada table di bawah ini:

Tabel 1. Pengkodean Buku

\begin{tabular}{|l|l|l|}
\hline NO & $\begin{array}{l}\text { KELAS } \\
\text { PENGGUNA }\end{array}$ & KODE BUKU \\
\hline & KELAS III & A \\
\hline 2 & KELAS VI & B \\
\hline
\end{tabular}


Dalam penelitian kualitatif, peneliti adalah instrument kunci. Namun untuk mendukung proses penelitian, dilakukan triangulasi instrument penelitian. Penelitian ini diawali dengan wawancara lapangan untuk menggali informasi berhubungan dengan buku teks yang digunakan di sekolah. Kemudian, instrument lainnya yang digunakan pada penelitian ini adalah lembar ceklis

Adapun format lembar ceklis adalah sebagai berikut:

Tabel 2. Format Kesesuaian Karakter Pembelajar dengan Buku Teks yang digunakan

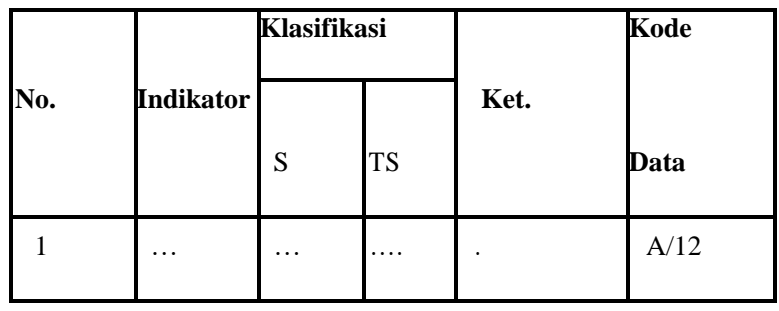

Keterangan Tabel:

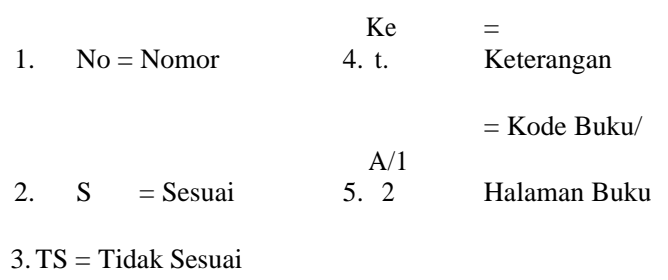

Dalam pelaksanaan penelitian ini, data penelitian akan dikumpulkan dengan menggunakan 2 teknik di bawah ini:

\section{Observasi}

Kegiatan observasi dilaksanakan oleh petugas survey guna mendapatkan informasi tentang jenis buku teks yang digunakan di sekolah lokasi penelitian.

2. Studi Kepustakaan

Peneliti juga menggunakan studi kepustakaan dan rujukan referensi lainnya. Hal ini diperlukan untuk membantu mendapatkan landasan teori pada penelitian.

\section{E. Teknik Analisis Data}

Analisis data dalam penelitian ini mencakup empat tahap, yaitu (1) reduksi data, (2) triangulasi (3) penyajian data, dan (4) penarikan simpulan.

\section{Alur Pikir Penelitian}

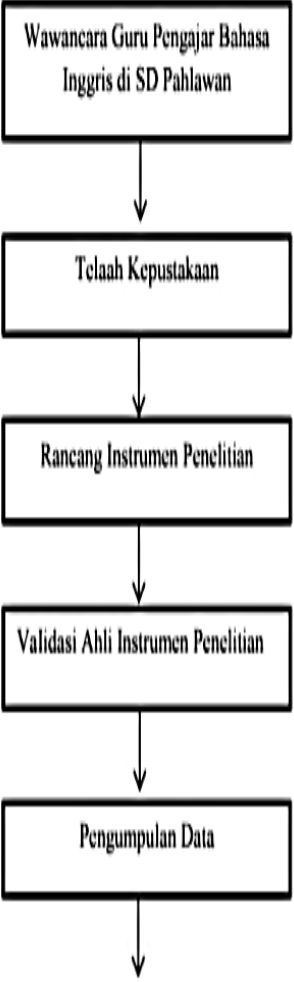

Pengolahan Data Pra Analisis

a. Koding

b. Klasifikasi Data

c. Reduksi Daia

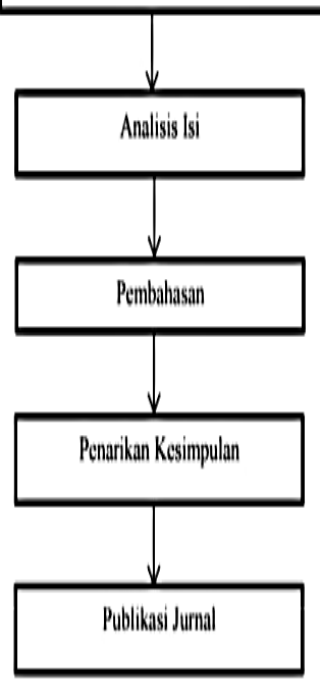




\section{HASIL DAN PEMBAHASAN}
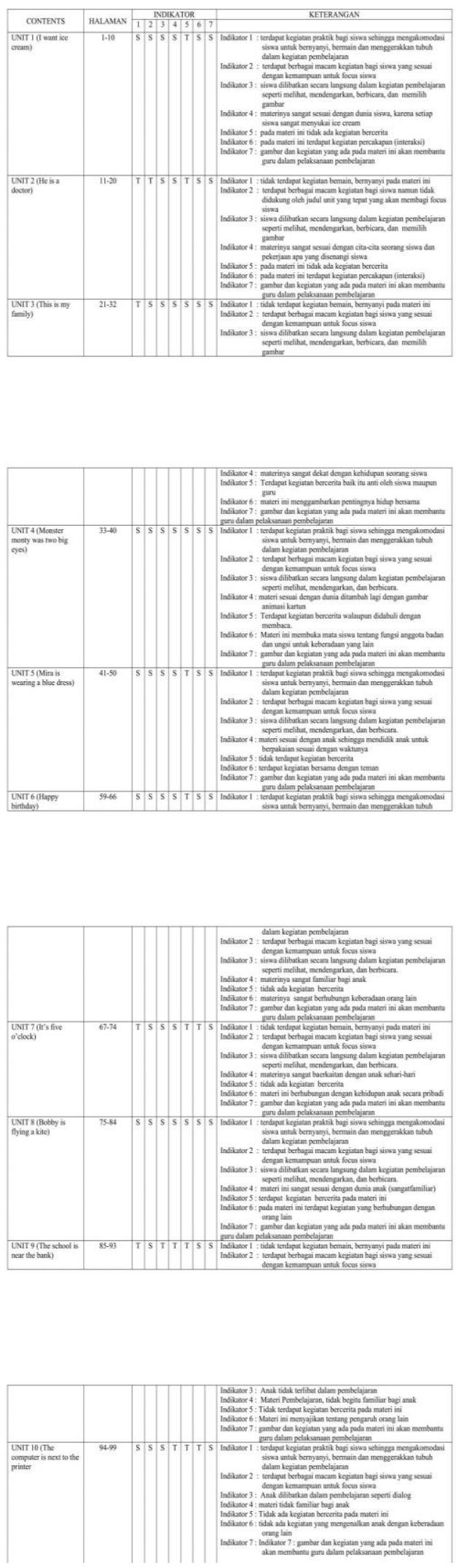

Unit 1 (I want ice cream) buku teks bahasa inggris kelas 3 dapat dilihat bahwa dari 7 indikator karakter pembelajar muda terdapat 6 indikator yang ada pada buku teks sedangkan 1 indikator tidak terdapat pada buku teks unit 1 . Pada indikator 1 terdapat kegiatan praktik bagi siswa baik itu dialog (3,5,dan 7), memilih gambar (2 dan 9) serta bernyanyi (10). Indikator 2 yang mengatakan bahwa karakter pembelajar muda itu ialah yang memiliki focus yang terbatas, sesuai dengan isi buku teks pada unit 1 yang memberikan petunjuk dan langkah-langkah pembelajaran yang jelas sehingga membuat siswa mudah untuk mengikuti pembelajaran. Indikator 3 tentang keterlibatan siswa secara langsung dalam pembelajaran, ini juga terdapat pada unit 1 yang materi pembelajarannya melibatkan anak secara langsung, baik itu seperti berdialog/berbicara dengan temannya, melihat dan memilih gambar yang berdampak siswa termotivasi dalam mengikuti pembelajaran. Indikator 4 tentang anak yang mudah memahami materi pembelajaran yang berdekatan dengan dunia mereka, pada unit 1 dalam buku teks ini juga mengemas materi pembelajaran yang sangat berdekatan dengan dunia mereka seperti ice cream.

Indikator 5 tentang kegiatan bercerita yang lebih disenangi oleh anak, pada unit ini tidak terdapat kegiatan bercerita, pada indikator 6 yang mengatakan bahwa karakter pembelajar muda pada usia 10 , anak sudah mulai mengenal keberadaan oran lain dan buku menyajikan kegiatan dialog atau interaksi dengan temannya yang mana ini sangat membantu siswa untuk memahami tentang keberadaan orang lain. Sedangkan pada indikator 7 yang menyatakan bahwa hal 
yang bersifat konkret disertai objek nyata dan gambar lebih memudahkan pelaksanaan proses pembelajaran, pada unit 1 materi pembelajaran pada buku ini dikemas dengan menyertai objek dan gambar bahkan guru juga membawa benda nyata dalam pembelajaran sehingga ini dapat dikatakan sesuai dengan karakter pembelajar muda pada indikator 7 .

Pada unit 2 (He is a doctor) terdapat 4 indikator yang sesuai dengan karakter pembelajar muda dan 3 indikator yang tidak terdapat pada buku teks, Indikator 1, 2 dan 5 tidak terdapat pada unit 2 dalam buku teks. Indikator 3 yang berkaitan dengan karakter anak yang lebih termotivasi dalam pembelajaran ketika mereka terlibat secara langsug dalam proses pembelajaran seperti pada petunjuk 'listen and practice' dan 'complete the sentences and practice with your fiends' yang membuat siswa terlibat langsung dalam prose pembelajaran. Indikitor 4 tentang materi yang sesuai dengan karakter siswa, juga sesuai pada unit 2 karna menerangkan materi yang sesuai dengan cita-cita seorang siswa pada kelas 3 SD. Indikator 6 pada buku teks juga sesuai dengan isi teks pada, buku yaitu siswa diajak untuk berinteraksi bersama temannya sehingga siswa mengenal keberadaan orang lain. Sedangkan pada indikator 7 sesuai dengan isi unit 2 yang materinya dikemas dengan menyertai objek dan gambar. Pada Unit 3 (This is my family) terdapat 6 indikator yang sesuai dengan isi dan 1 indikator yang tidak sesuai. Indikator 1 tidak terdapat kegiatan bermain, bernyanyi pada mataeri ini sedangkan pada indkator 2-7 menunjukkan kesesuaian dengan karakter seorang pembelajar muda.

Pada unit 4 (Monster monty was two big eyes) semua indicator karakter pembelajar muda terdapat pada materi unit 4 ini seperti praktik bernyanyi, materi yang sesuai dengan focus mahasiswa, siswa dilibatkan dalam kegiatan pembelajaran, materi yang sesuai dengan dunia anak, tedapat kegiatan bercerita walaupun didahullui dengan membaca terlebih dahulu, kegiatan berdialog dengan teman dan terdapat gambar yang mendukung pelaksanaan pembelajaran. Pada unit 5 (Mira is wearing a blue dress) terdapat satu indicator ang tidak sesuai dengan karakter pembelajar muda yaitu pada indicator 5 tentang kegiatan bercerita yang lebih disukai oleh anak,namun indicator-indikator yang lain tergambarkan pada materi unit 5 ini.

Unit 6 (Happy Birthday), pada unit 6 ini sama dengan materi sebelumnya yaitu terdapat 1 indicator yang tidak ada pada materi ini yaitu kegiatan becerita, namun indicator yang lainnya tegambarkan pada materi ini seperti kegiatan bernyanyi dan bermain, memuahkan focus siswa, student center, materi yang sangat familiar dan digemari seorang anak dan berhubungan dengan orang lain atau temannya sendiri, dan ditunjang dengan gambar. Pada unit 7 (It's five o'clock) terdapat 3 indikator yang tidak tergambarkan pad materi ini seperti pada indicator 1 tidak terdapat kegiatan bernyanyi pada materi ini, tidak ada kegiatan bercerita pada indicator 5, tidak ada kegiatan yang berhubungan dengan keadaan orang lain melainkan kehidupan anak secara pribadi, namun 4 indikator lainnya terggambarkan pada materi ini.

Unit 8 (bobby is flying a kite), pada unit ini semua indicator karakter pembelajar muda tergambarkan pada materi ini seperti terdapat kegiatan praktik dan bernyanyi bagi siswa, pemaparan materi yang sesuai dengan kemampuan focus siswa, materi nya bersifat student center, materinya sangat familiar bagi siswa, terdpat kegiatan bercerita meskipun 
didahului dengan bacaan, terdapat kegiatan berdialog dan materi ini didukung gambar atau animasi yang digemari oleh siswa.

Pada unit 9 (The school is the near the bank) terdapat 4 indikator tentang karakter pembelajar muda yang tidak tergambarkan pada materi ini seperti tidak terdapat kegiatan bernyayi dan bermain dalam materi ini, anak tidak terlibat dalam kegiatan pembelajaran, materi yang tidak familiar bagi siswa dan tidak terdapat kegiatan bercerita bagi siswa pada materi ini. Sedangkan 3 indikator karakter pembelajar muda tergambarkan pada materi ini seperti pembagian focus pada materi ini, pengaruh orang lain, dan terdapat gambar atau animasi yang sesuai dengan karakter siswa. Unit 10 (the computer is nexo the printer) terdapat 4 kegiatan yang sesuai dengan karakter pembelajar muda seperti kegiatan praktik bagi siswa seperti bernyanyi, pemaparan materi sesuai dengan kemampuan siswa untuk focus dalam pembelajaran, materi yang bersifat student center dan terdapat gambar yang sesuai dengan karakter anak, namun terdapat 3 indikator yang tidak tergambarkan pada materi ini, seperti materi yang tidak familiar bagi siswa, tidak terdapat kegiatan bercerita dan tidak terdapat kegiatan yang mengenalkan anak kepada orang lain

\section{SIMPULAN}

Kegiatan pembelajaran adalah merupakan serangkaian kegiatan yang melibatkan beberapa komponen. Keterlibatan komponen ini saling menimbulkan interaksi. Salah satu komponen penting yang hadir dalam kegiatan pembelajaran adalah buku teks. Buku teks sebagai bahan ajar berfungsi membantu guru dalam menyampaikan tujuan pembelajaran. Ini dapat dikatakan bahwa Buku Teks merupakan komponen utama untuk berlangsungnya kegiatan pembelajaran.
Sehubungan dengan perannya yang esensial dalam proses pembelajaran, sebuah buku teks harus mempertimbangkan komponen lain yang terlibat dalam proses pembelajaran. Hal yang paling utama adalah berkaitan dengan peserta didik yang merupakan pengguna buku teks. Buku teks harus disessuaikan dengan penggunanya, karena buku teks ini diberlakukan disekolah, berarti penggunanya adalah siswa.Keberadaan peserta didik harus menjadi faktor penimbang utama guru dalam menyajikan bahan ajar. Mendiknas (2008:6) mengemukakan bahwa "bahan ajar merupakan bahan pembelajaran yang digunakan untuk membantu siswa belajar".

Buku teks sebagai bahan ajar dituntut untuk mampu mempermudah siswa dalam memahami pembelajaran. Sejalan dengan hal tersebut, buku teks yang baik dalam pembuatannya melibatkan karakteristik siswa. Hal ini dikarenakan karakteristik mempengaruhi kegiatan pembelajaran. Karakteristik berkaitan dengan kualitas diri yang dimiliki seorang individu. Memahami karakter berarti melakukan identifikasi terhadap individu. Hal ini penting dikarenakan ada hubungan yang kuat antara katrakter siswa dan proses pengembangan instruksional.

Lebih lanjut pembelajaran yang berhubungan dengan bahasa asing, dalam hal ini pembelajaran Bahasa Inggris. Kegiatan pembelajaran bahasa inggris yang merupakan pembelajaran bahasa asing di Indonesia dalam adaptasinya membutuhkan keselarasan dalam penyajian materi. Buku teks yang merupakan sumber pembelajaran harus mampu memberikan kesesuaian antara karakter siswa dan buku teks yang digunakan. Ini dikarenakan, dalam buku teks memuat kegiatan pebelajaran yang terdiri dari berbagai kegiatan pembelajaran. Penyajian buku ajar yang sesuai dengan karakter siswa diharapkan akan mampu mempermudah tercapainya tujuan pembelajaran.

Sejalan dengan pentingnya peranan karakteristik siswa dalam pembelajaran yang 
berhubungan dengan buku teks, dirasa perlu diadakannya sebuah kegiatan ilmiah untuk menganalisa dan menyajikan gambaran lapangan tentang relevansi buku teks yang digunakan guru dalam pembelajaran bahasa Inggris dan Karakter siswa pengguna.

Penelitian ini merupakan penelitian analisis isi dengan menggunakan dokumen berupa buku teks bahasa inggris yang digunakan dalam pembelajaran bahasa inggris pada siswa kelas III yang digunakan oleh sekolah sebagai subjeknya. Rancangan penelitian menggunakan teknik analisis isi untuk mendeskripsikan secara objektif, sistematis, dan komunikatif isi yang tampak dengan menggunakan seperangkat prosedur untuk menarik kesimpulan. Peneliti juga akan melakukan teknik observasi untuk mendapatkan gambaran terkait karakter pembelajar muda dalam proses pembelajaran. Untuk memvalidasi data, peneliti melakukan teknik wawancara terhadap guru guna melihat pendapat dan menggali pengalaman guru dalam melakukan pembelajaran di kelas dengan menggunakan buku teks yang digunakan. Penelitian ini akan dilaksanakan di SD Pahlawan yang beralamat Jl. Akper Desa Ridan Permai, Kec.Bangkinang Kota,kab. Kampar. Luaran yang dihasilkan dalam penelitian adalah Jurnal dan prosiding yang dipublikasikan di tingkat Nasional.

Tingkat Kesiapan Teknologi (TKT) yang dihasilkan dari penelitian ini adalah berupa konsep terkait kesesuaian karakteristik siswa dan buku teks yang digunakan. Adapun level TKT yang dihasilkan dari penelitian ini adalah pada level 2.

\section{DAFTAR PUSTAKA}

De Porter, Bobbi dan Hernacki, Mike. 1992. Quantum Learning. Membiasakan Belajar Nyaman dan Menyenangkan. Terjemahan oleh Alwiyah Abdurrahman. Bandung: Penerbit Kaifa.

Fauziddin. 2014. Pembelajaran PAUD Bermain Cerita Menyanyi Secara Islami. Bandung. PT. Remaja Rosda Karya.
Sujimat, D. Agus. 2000. Penulisan karya ilmiah. Makalah disampaikan pada pelatihan penelitian bagi guru SLTP Negeri di Kabupaten Sidoarjo tanggal 19 Oktober 2000 (Tidak diterbitkan). MKKS SLTP Negeri Kabupaten Sidoarjo

Suparno. 2000. Langkah-langkah Penulisan Artikel Ilmiah dalam Saukah, Ali dan Waseso, M.G. 2000. Menulis Artikel untuk Jurnal Ilmiah. Malang: UM Press.

UNESA. 2000. Pedoman Penulisan Artikel Jurnal, Surabaya: Lembaga Penelitian Universitas Negeri Surabaya. 